\title{
Antioxidant molecular mechanism of adenosyl homocysteinase from cyanobacteria and its wound healing process in fibroblast cells
}

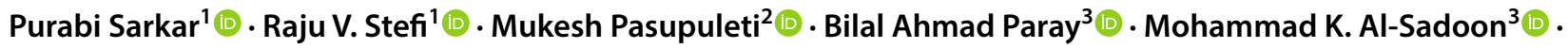 \\ Jesu Arockiaraj ${ }^{1}$ (i)
}

Received: 20 November 2019 / Accepted: 22 January 2020 / Published online: 27 January 2020

(c) Springer Nature B.V. 2020

\begin{abstract}
An antioxidant molecule namely, adenosyl homocysteinase (AHc) was identified from the earlier constructed transcriptome database of Spirulina, where it was cultured in a sulphur deprived condition. From the AHc protein, a small peptide NL13 was identified using bioinformatics tools and was predicted to have antioxidant property. Further, the peptide was synthesised and its antioxidant mechanism was addressed at molecular level. NL13 was subjected to various antioxidant assays including DPPH assay, HARS assay, SARS Assay, NO assay and ABTS assay, where NL13 exhibited significant $(\mathrm{P}<0.05)$ potential antioxidant activity compared to its antioxidant control, Trolox. Cytotoxicity was performed on Human whole blood and the cell viability was performed on VERO fibroblast cells. In both assays, it was found that NL13 did not exhibit any cytotoxic effect towards the cells. Further, the intracellular ROS was performed on Multimode reader followed by imaging on fluorescence microscope which showed scavenging activity even at lower concentration of NL13 (31.2 $\mu \mathrm{M})$. An effective wound healing property of NL13 on VERO cells was confirmed by analysing the cell migration rate at two different time intervals (24 and 48 h). Overall, the study shows that NL13 peptide scavenges the intracellular oxidative stress.
\end{abstract}

Keywords Cyanobacteria $\cdot$ Adenosyl homocysteinase $\cdot$ Wound healing $\cdot$ Fibroblast cells $\cdot$ Spirulina

\section{Abbreviations}

AHc Adenosyl homocysteinase

ROS Reactive oxygen species

Ap Arthrospira platensis

TEAE Trolox equivalent antioxidant capacity

HRS Hydroxyl radical scavenging

VERO Fibroblast cells

Electronic supplementary material The online version of this article (https://doi.org/10.1007/s11033-020-05276-y) contains supplementary material, which is available to authorized users.

Jesu Arockiaraj

jesuaroa@srmist.edu.in

Purabi Sarkar

purabisp@srmist.edu.in

Raju V. Stefi

stefir@srmist.edu.in

Mukesh Pasupuleti

mukesh.p@cdri.res.in

Bilal Ahmad Paray

bparay@ksu.edu.sa

Mohammad K. Al-Sadoon

msadoon@ksu.edu.sa

\section{Introduction}

Sulfur is one of the most essential nutrients required by cyanobacteria for their growth, metabolism and regulation. Sulphur stress has shown deleterious effect on the growth of cyanobacteria $[1,2]$. Adenosyl homocysteinase $(\mathrm{AHc})$ is also known as S-Adenosyl homocysteinase hydrolase; this is an enzyme that hydrolyses to adenosine and L-homocysteinase [2,3]. Adenosyl homocysteinase plays a major role in regulating methylation and controlling its intracellular

1 SRM Research Institute, SRM Institute of Science and Technology, Kattankulathur, Chennai, Tamil Nadu 603 203, India

2 Lab PCN 206, Microbiology Division, CSIR-Central Drug Research Institute, B.S. 10/1, Sector 10, Jankipuram Extension, Sitapur Road, Lucknow, Uttar Pradesh 226031 , India

3 Department of Zoology, College of Science, King Saud University, PO Box 2455, Riyadh 11451, Saudi Arabia 
concentration. It acts as a catalyst in a chemical reaction by regulating the levels of S-Adenosylhomocysteine. S-Adenosylhomocysteine is very important for transmethylation reaction. According to studies [4-6], AHc can act as anticryptosporidial drug, antiviral, antitumor, antioxidant and antimalarial agents.

Reactive oxygen species (ROS) imbalance play a crucial role in wound healing impairment. A wound can be an injury in any normal tissue by physical, thermal, chemical or microbial effects that results in damaging tissues at molecular and cellular levels. Wound healing is a vital biochemical and physiological process that can be challenged due to free radicals. The process of wound healing takes place in three successive phases such as inflammation phase, tissue formation phase and remodelling phase [5]. Proinflammatory cytokines and growth factors are secreted by white blood cells during inflammation. It is followed by strengthening of new granulation tissue by laying collagen in the wound by fibroblasts. In the third phase, the new cells are formed around the wound and new matrix is created which reduces the extracellular matrix and its component [6].

Antioxidants help in balancing the oxidative stress and allow regeneration of tissue by repairing the cells. At the site of injury, excess amount of protease and reactive oxygen species are formed by the accumulation of neutrophils and it restricts the oxidative damage of protease inhibitor [7]. Reactive oxygen species is developed at the wound site in larger quantities as a protection against invasive bacteria. The existence of increased number of neutrophils and ROS, nevertheless, overwhelms the antiprotease substances that usually shield the cells and extracellular matrix. Reactive oxygen species can cause severe tissue damage at high concentrations and even contribute to neoplastic transformation, which inhibits the healing process through disruption of cell membranes, DNA, proteins and lipids. Fibroblasts can be killed and excess ROS make skin lipids less flexible. As a consequence, the ultimate involvement of antioxidants in the successful treatment and maintenance of wound tends to be important. Such adverse effects of wounds are minimized due to antioxidants by eliminating inflammatory compounds. They counteract the excess proteases and ROS which are often produced due to the accumulation of neutrophils in the injury [6,7]. Antioxidant protection is a mechanism that includes the interaction between the compound and the hydroxyl peroxidase rather than just limiting the cell membrane damage [8]. Many compounds have been reported to show wound healing activity with the property of high radical scavenging capacity [6].

Arthrospira platensis ( $A p)$ is a filamentous planktonic blue-green alga (also called cyanobacteria) that is increasing more attention due to its nutritional and medicinal values. Phenolics, phycocyanins and polysaccharides present in spirulina have shown anti-inflammatory and antioxidant properties. Spirulina has shown to increase the activation of macrophages and reduction of inflammation without effecting innate defense system [9]. Abdel-Daim et al. reported that the inflammation improved various oxidative stress markers including nitric oxide, glutathione peroxidase, superoxide dismutase and reduced glutathione in mice model [10]. Spirulina has bioactive compounds that help in the inactivation of free radicals protecting against stress [11-13]. Cyanobacterial metabolites reveal interesting and exciting bioactivities such as anticoagulant, immunosuppressant, antimalarial, antiviral and antibacterial [14]. Cyanobacteria are potentially considered for preventing vascular damage as well as cardiovascular diseases, providing defense by scavenging the free radicals and acts as a UV-B screening compounds [15].

The use of antioxidant peptides has given a new approach towards the therapeutic techniques. The molecular weight, isoelectric point, amino acid composition, hydrogen ion concentration, structure and hydrophobic characters are essential criteria to sequence the antioxidant peptides [16]. Several antioxidant compounds have been reported with wound healing activity. In the line, peptides derived from hydrolysate of A. platensis has also exhibited antioxidant activity by inhibiting lipid peroxidation formation and by donating hydrogen to act as free radical scavengers [17]. Therefore, this study focuses on the sulphur stressed antioxidant peptide and its activities including on fibroblast cells.

From the transcriptome of A. platensis, ApAHc sequence was obtained which was cultured under sulphur deprived state that was constructed through Illumina NextSeq 500 technology. The recognised full-length sequence of cDNA was characterized using various bioinformatics analysis including multiple sequence alignment and physiochemical parameters. Further, the expression pattern of $A p A H c$ was analysed in real time PCR in A. platensis cells which was cultured under the sulphur deprived condition. A short peptide named NL13 was derived from S-adenosylhomocysteine hydrolase domain of ApAHc protein by bioinformatics analysis and it was synthesised to study its activities. NL13 peptide was predicted to have antioxidant property based on the conserved regions compared to the other known antioxidant cyanobacteria using BLAST. Also, other parameters like molecular weight $(1.33 \mathrm{kDa})$ and the presence of antioxidant amino acids such as Proline (7.7\%), Leucine (15.4\%), Alanine (15.38\%), Valine (7.7\%) and Aspartic acid $(15.4 \%)[18,19]$. The purity of the peptide was determined using HPLC and its sequence purity was confirmed by MS analysis. Further, the peptide was subjected to the determination of different physical and chemical properties using in silico tools. NL13 was also further subjected to various molecular assays including cytotoxicity and wound healing performance on VERO fibroblast cells under $\mathrm{H}_{2} \mathrm{O}_{2}$ stress to study its antioxidant potent. 


\section{Materials and methods}

\section{Growth analysis and collection of $A$. platensis cells}

The inoculum of $A$. platensis strain used in this study was isolated from Potheri Lake $\left(12.825527^{\circ} \mathrm{N} 80.039606^{\circ} \mathrm{E}\right)$ Tamil Nadu, India. It was grown in 11 flasks containing modified Zarrouk's medium (Cogne) at temperature $30{ }^{\circ} \mathrm{C}$, $\mathrm{pH} 9.5$ with a $12 \mathrm{~L} / 12 \mathrm{D}$ cycle [20]. The cells grown in Zarrouk medium was served as control. For analysing sulphur deprivation studies, A. platensis was cultured in an altered Zarrouk medium that was supplemented with 0 , $20,40,60,80$ and $100 \%$ chloride instead of sulphate. The growth rate of $A$. platensis was measured once in alternative days in spectrophotometer at $655 \mathrm{~nm}$. The culture was utilised to study the expression pattern of $A p A H c$, thus sampling was taken at every 5 days interval until the study was completed on day 20 . The collected cells were frozen immediately in liquid nitrogen and further stored at $-80^{\circ} \mathrm{C}$ until the gene expression study was evaluated.

\section{Validation of ApAHc gene expression by real time PCR}

Total RNA was extracted from the collected A. platensis cells using TRIzol method as suggested by manufacture (Life Technologies, Rockville, MD, USA). Then the extracted total RNA was subjected to the conversion of cDNA using the cDNA synthesis kit [17]. Utilizing the cDNA as template, the ApAHc gene expression was evaluated in Light Cycle 96 Real Time PCR system using Fast SYBR Green Master Mix (Roche Diagnostics GmbH, Germany). For the assay, we followed the standardised thermal protocol as reported earlier [21]. We have used $16 \mathrm{~s}$ rRNA as internal control to quantify the relative expression of ApAHc. For the assay the following primers were designed in Primer Quest tool and used for the assay: ApAHC, TGT CGT CGT TGT CGG TTA TG (Sense) and GAC TGG ATC AAC TTC GGT AAC A (Antisense) and 16 s RRNA, CGT AAA CCT CTC CTC AGT TCA G (Sense) and GAA CGG ATT CAC CGC AGT AT (Anti sense).

\section{Identification and sequence analysis of ApAHc}

A Sequence ApAHc was obtained from the transcriptome of A. platensis which was cultured under sulphur deprived state and was constructed earlier using Illumina NextSeq 500 technology [20]. The obtained ApAHc cDNA sequence was presented to the European Nucleotide Archive (EMBL Nucleotide Sequence Database) under ExPASy Translate (web.expasy.org) tool and received the protein sequence.
BLAST database (blast.ncbi.nlm.nih.gov) was used to search homology. Bioedit (ver. 7.1.3.0) (www.mbio.ncsu.edu) has been used to predict the multiple sequence alignment. PepCal and Peptide 2.0 (www.peptide2.com) were anticipated to use MEGA X (www.megasoftware.net) for phylogenetic analysis. Amino acid sequences were aligned using EMBLEBL (www.ebi.ac.uk) and 3D structure was built using the I-TASSER (https://zhanglab.ccmb.med.umich.edu/I-TASSE $\mathrm{R} /$ ). PyMOL (www.pymol.org) is used to render 3D models. The anticipated 3D structure was projected to be accurate based on I-TASSER confidence score (C-) and RMSD (Ramachandran Plot Analysis). Prabi-Gerland web server (www.prabi.fr) was conducted for additional details on 2D structure.

\section{Analysis of NL13 peptide}

Peptide NL13 characterization was performed based on (i) molecular weight (ii) amino acid properties, (iii) length, (iv) hydrophobicity and (v) amino acid content. ProtParam Tool- Expasy (https:/web.expasy.org/cgi-bin/protparam/ protparam) has been used to verify the number of amino acids, molecular weight, theoretical value, amino acid composition and instability index. Peptide 2.0 (https://www.pepti de2.com/) was used to check the attribute and hydrophobicity of the peptide NL13. Helical wheel projection program (www.rzlab.ucr.edu) was used to demonstrate the nature of predicted peptide. Pepdraw (www.pepdraw.com) was used to find the peptide linear structure. The determined NL13 peptide has $95.843 \%$ purity on HPLC Analysis and MALDITOF MS assessment has confirmed the NL13 sequence. The peptide was then made into a stock solution of $1 \mathrm{mM}$ and preserved at $-20{ }^{\circ} \mathrm{C}$ until further experiment on it.

\section{Determination of antioxidant action of NL13}

To examine the antioxidant activity of the NL13, the following assays were performed: DPPH assay, ABTS-Trolox equivalent antioxidant capacity (TEAE) assay, Hydroxyl radical scavenging activity, Super anion radical scavenging assay and Nitric oxide scavenging activity.

\section{DPPH radical scavenging assay}

The radical scavenging 2,2-diphenyl-1-picrylhydrazyl assay was determined based on the method provided by Sannasimuthu et al. [22] with slight modifications. Peptides or Trolox were blended with $0.5 \mathrm{ml}$ of DPPH $(25 \mu \mathrm{g}$ / ml) solution at distinct concentrations (250 to $7.8 \mu \mathrm{M})$. The blend was at the point of incubation in a dark place at room temperature for $30 \mathrm{~min}$. Ethanol was used as a control. The absorbance was taken at $517 \mathrm{~nm}$ on Microplate reader (TECAN, Austria) in triplicates. 


\section{ABTS assay}

The ABTS (2,2'-azino-bis-3-ethylbenzothiazoline-6-sulfonic acid) radical assay was freshly prepared by dissolving ABTS $(7 \mathrm{mM})$ in distilled water and by reacting it with potassium persulphate $(2.4 \mathrm{mM})$ [23]. After $12-16 \mathrm{~h}$, the reaction mixture was diluted with PBS ( $\mathrm{pH} 7.4)$, peptide samples or Trolox were added at different concentrations $(250$ to $7.8 \mu \mathrm{M})$ and kept for $60 \mathrm{~min}$ at $30^{\circ} \mathrm{C}$ [17]. The reading were taken in the Microplate reader at $734 \mathrm{~nm}$.

\section{Hydroxyl radical scavenging assay}

The assay was conducted as described by Sannasimuthu et al. [22] with some modifications. A reaction mixture was prepared in micro centrifuge tube that contained $30 \mu \mathrm{l}$ phenonthroline $(2 \mathrm{mM}), 30 \mu \mathrm{l}$ ferrous sulphate $(2 \mathrm{mM})$, $30 \mu \mathrm{l}$ EDTA $(6 \mathrm{mM})$ and PBS $(0.2 \mathrm{mM})$, along with the mixture, $40 \mu \mathrm{l}$ peptide or Trolox was added at different concentration ( 250 to $7.8 \mu \mathrm{M}$ ). Finally, $40 \mu \mathrm{l}$ of $0.03 \%$ $\mathrm{H}_{2} \mathrm{O}_{2}$ was added in each tube and incubated for $37^{\circ} \mathrm{C}$ for $60 \mathrm{~min}$. Absorbance was taken at $536 \mathrm{~nm}$ using microplate reader and the readings were recorded. The experiments were repeated in three replicates.

\section{Superoxide anion radical scavenging assay}

The superoxide anion radical was produced [17] using $50 \mu 1$ nitrotetrazolium blue chloride $(2.52 \mathrm{mM}), 50 \mu 1$ NADH $(624 \mathrm{mM})$ and different concentrations of peptide (250 to $7.8 \mu \mathrm{M})$. The reaction was started by including $50 \mu \mathrm{l}$ phenazine methosulfate solution to the mixture. The absorbance of the arrangement was measured at $560 \mathrm{~nm}$.

\section{Nitric oxide assay}

To perform the assay, sodium nitroprusside $(5 \mathrm{mM})$ was prepared [24] in PBS and was kept for $2 \mathrm{~h}$ at $25^{\circ} \mathrm{C}$. After incubation, the peptide at different concentration was added. Further, it was treated with Griess reagent (1\% sulphanilamide, $0.1 \%$ NEED and $2.5 \%$ phosphoric acid) and the absorbance was taken at $540 \mathrm{~nm}$ in microplate reader.

\section{Determination of cytotoxicity and intracellular ROS level in human blood cells}

Haemolytic assay was applied to find out the cytotoxicity of NL13 on human blood cells by isolating human PBMC.
In addition, intracellular ROS level was analysed using DCFDA dye under fluorescence microscope.

\section{Haemolytic assay on human whole blood}

Blood was acquired from a healthy volunteer (Ethical Clearance No. CDRI/IEC/2014/A1) with a $5 \mathrm{ml}$ syringe and gathered in BD Vacutainer (EDTA Coated, REF-367841) to avoid coagulation [25]. Blood $(2 \mathrm{ml})$ was centrifuged at $1000 \mathrm{rpm}$ for $10 \mathrm{~min}$ at $4{ }^{\circ} \mathrm{C}$ in cooling centrifuge. Plasma was removed and erythrocytes were washed thrice in $1 \mathrm{X}$ PBS and was centrifuge for $5 \mathrm{~min}$ at $500 \mathrm{rpm}$. The supernatant was collected in 96 well microplate along with the peptide, NL13 $(250 \mu \mathrm{M})$. For positive control, Triton X-100 and as negative control, 1X PBS was used. The results were noted using microplate reader at $540 \mathrm{~nm}$ in three replicates.

\section{Analysis of intracellular ROS level on leucocytes}

The antioxidant activity of NL13 was determined using intracellular fluorescent probe assay $[17,26]$ on human leucocytes. Hydrogen peroxide was added as a radical generator and the ability of NL13 to remove the generated oxidative stress was measured using multimode microplate reader (Thermo Scientific) with excitation $\lambda=498 \mathrm{~nm}$ and emission $\lambda=530 \mathrm{~nm}$. Cells were seeded in a 96 well plate and were incubated with $10 \mu \mathrm{M}$ DCFDA. The reaction mixture was prepared by adding $20 \mu \mathrm{l}$ of $30 \% \mathrm{H}_{2} \mathrm{O}_{2}$ in each well and was incubated for $30 \mathrm{~min}$ along NL13 at different concentration $(250$ to $7.8 \mu \mathrm{M})$ at $37^{\circ} \mathrm{C}$. Further, $2 \mathrm{~h}$ incubation, the readings were recorded and the images were observed under fluorescence microscope (Leica) at 10X objective.

\section{Effect of peptide on cell line by MTT assay}

The cytotoxicity impact of NL13 peptide was also tested on VERO cells (fibroblasts) obtained from the kidney cells of African green monkey (Cercopithecus aethiops) using MTT assay [27]. The cells were acquired from National Centre for Cell Science (NCCS), Pune. The cells were seeded in 96 wellplated microplates $\left(1 \times 10^{6}\right.$ cells/well $)$ and kept in $5 \% \mathrm{CO}_{2}$ incubator at $37{ }^{\circ} \mathrm{C}$ for $48 \mathrm{~h}$ and allowed them to develop $80 \%$ confluence. The medium was then substituted and the cells were treated with NL13 at different concentration $(7.8,15.6$, $31.2,62.3,125$ and $250 \mu \mathrm{M}$ ) and incubated for $24 \mathrm{~h}$. The absorbance was read spectrometrically at $570 \mathrm{~nm}$ employing a LIZA microplate reader. Morphological modifications of control cells and treated cells were noted beneath inverted magnifying lens (Magnus, INVI, Noida) and were photographed. Percentage of cell viability was calculated using the following equation: cell viability $(\%)=\left(\mathrm{OD}_{\text {Sample }} / \mathrm{OD}_{\text {Control }}\right) \times 100$. 


\section{In-vitro scratch assay}

VERO cells were seeded in 6 -well plates $\left(6 \times 10^{5}\right.$ cells/well $)$ and grown in optimum crop conditions until a confluence of $90 \%$ was reached [28]. In cell monolayer, a scratch was made by a P10 pipette tip, to impersonate an injury to imitate a wound, and cell debris was evacuated by washing with new medium. The wound was exposed at $37{ }^{\circ} \mathrm{C}$ in a humidified atmosphere of $5 \% \mathrm{CO}_{2}$ for $48 \mathrm{~h}$. Scratch wound closure was analyzed beneath the inverted magnifying instrument (Magnus INVI, Noida) prepared with a computerized CCD camera, by securing computerized pictures at distinctive time $0 \mathrm{~h}\left(\mathrm{~T}_{0}\right), 24 \mathrm{~h}\left(\mathrm{~T}_{1}\right)$ and $48 \mathrm{~h}\left(\mathrm{~T}_{2}\right)$ (static imaging). The closure of the scratch was measured by determining the contrast between the wound width at $\mathrm{T}_{0}$ and $\mathrm{T}_{1} / \mathrm{T}_{2}$, utilizing the ImageJ preparing program. Peptide free media was used as a control.

\section{Statistical analysis}

The values provided in the study is the average of three replicates \pm standard deviation. All the statistical studies were performed utilising Bonferroni post hoc test and Turkey's multiple comparison analysis at the importance level 5\% and $1 \%$ in Graph Pad Prism 5.0.

\section{Results and discussion}

\section{Expression of ApAHc on sulphur stress of $A$. platensis}

To understand the growth pattern of spirulina cells at sulphur stressed condition in modified Zarrouk medium was measured by real time PCR analysis. The mRNA expression of $A p \mathrm{AHc}$ was analysed at different interval of time $(0,5,10$, 15 and 20 days). However, it was found that there was significant $(\mathrm{P}<0.01)$ higher expression of ApAHc on day 10 followed by day $15(\mathrm{P}<0.05)$. On day 20 , it was observed that the ApAHc expression was nearly to the basal level (Fig. 1). Sannasimuthu et al. noticed the highest expression in spirulina due to $\mathrm{H}_{2} \mathrm{O}_{2}$ stress on day 5 [17]. Moreover, Leal et al. [27] observed downregulation of AHc which leads to tumorigenesis. In contrast, overexpression of AHc in HEK293 cells affected the adenosine level, DNA methylation and cell viability [29]. In our study, we observed the highest expression on day 10 in $A p A H c$ due to the stress influence.

\section{Bioinformatic characterisation of ApAHc}

\section{Analysis of ApAHc whole sequence}

The cDNA sequence ApAHc obtained from the earlier constructed transcriptome of A. platensis [20] was submitted

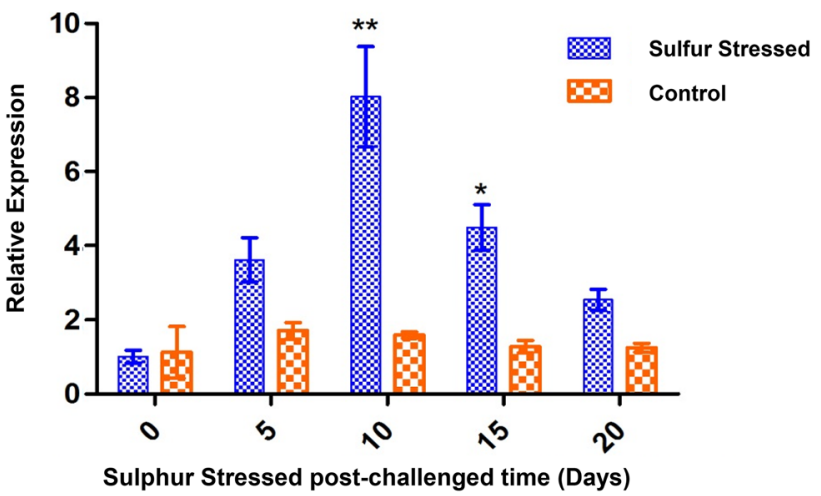

Fig. 1 Gene expression patterns of ApAHc by qRT-PCR. Data are expressed as a relative fold at different interval of time $(0,5,10,15$ and 20 days). Values are shown as mean \pm standard deviation of three replicates. Single asterisk $\left(^{*}\right)$ represents $\mathrm{P}<0.05$ and double asterisk (**) represents $\mathrm{P}<0.01$ compared to their respective controls by Bonferroni post hoc test in Graph Pad 5.0

to EMBL database under the accession No. LT838802. The physio-chemical properties of ApAHc were determined by DNAssist software (ver. 2.2). The obtained results data signified that $A p A H c$ has a coding region of 1281 base pairs, that encodes a protein of 426 amino acids capable of $46.509 \mathrm{k}$ Da as molecular weight and 5.53 as isoelectric point (pI). The amino acids consist of three domains namely S-adenosyl homocysteine hydrolase coenzymes transport metabolism as the biggest domain $\left({ }^{9}\right.$ Lys- $\left.\mathrm{Th}^{425}\right)$, S-adenosyl-L-homocysteinehydrolase $\left({ }^{10} \mathrm{Tyr}-\mathrm{Thr}^{425}\right)$ and S-Adenosyl homocysteine hydrolase NAD-binding site catalytic domain $\left({ }^{19} \operatorname{Pro}-\operatorname{Tr} \mathrm{p}^{421}\right)$ with four different motifs which forms the NAD binding site, ligand binding site, polypeptide binding site and catalytic site (Data shown in E-Suppl. File Fig. 1). S-adenosyl homocysteine hydrolase forms the biggest domain $\left({ }^{9} \mathrm{Lys}-\mathrm{Thr}^{425}\right)$ in $A p A H c$ that is a potent inhibitor of S-adenosyl-L-methionine and plays a major role in modulating the methyltransferase activity. SabH composed of two domains includes cofactor binding domain and substrate-binding domain [30] which is present in $A p A H c$. The homocysteine precursor present in the AHc is strongly correlated with cardiovascular disease and growth of atherosclerosis [31]. However, recently reported that $\mathrm{AHc}$ also helps in regulating oxidative stress level in patients suffering from coronary artery diseases and also prevents endothelial dysfunction [32]. Also, deficiency of AHc promotes oxidative stress by decreasing $\mathrm{Na}^{+}$, $\mathrm{K}^{+}$-ATPase activity in cerebral cortex of rats by increasing S-adenosylmethionine [33].

\section{ApAHc homology search and its phylogeny}

The protein sequence of $A p \mathrm{AHc}$ was compared with other homologous sequences including Planktothrix agardhi, Lyngbya aestuarii, Oscillatoriales cyanobacterium and Nostoc 
commune. The analysis indicated that the sequences considered for analysis have potential antioxidant properties by the presence of their conserved domains and motifs. Moreover, the multiple sequence analysis revealed that $A p \mathrm{AHc}$ has shown $99,87.2,87.06$ and $81.1 \%$ similarity with the homologues groups including $P$. agardh, L. aestuarii, O. cyanobacterium and $N$. commune, respectively (Data shown in E-Suppl. File Fig. 2). Multiple sequence analysis was done by grouping other cyanobacteria like P. agardhi [34], L. aestuarii, O. cyanobacterium and $N$. commune with A. platensis $[35,36]$ which has been reported to have antioxidant property. It is noted that the functional regions of $\mathrm{AHc}$ from all the species taken for analysis are highly conserved among them, which further proved the potentiality of the molecule. Also, the homology was highly conserved among the peptide regions (NL13) which was predicted to have potential antioxidant property.

The phylogenetic analysis of $A p A H c$ was performed using Mega 6.0 that indicates our ApAHc was clustered together with other filamentous algae Lyngbye aestuarii and formed a sister concern with Planktothrix agardhi. It may due to all these organisms fall in the cyanobacterial group. The construction was conducted using Neighbour-Joining method with 1000 bootstrap values (Data shown in E-Suppl. File Fig. 3). Further, this cyanobacterial group formed another cluster with plants; then finally formed a separate cluster with animals including fish, amphibians and mammals. Overall, the analysis showed the evolutionary relationship among the species. It is also meant that the protein plays a crucial role in the regulation of abiotic and biotic stress response in plants [37] and regulates oxidative stress in animals [32], which is confirming the clustering pattern due to their function that is involved in stress mechanism.

\section{Structural analysis of ApAHc}

The two-dimensional structure of ApAHc showed that it consists of 182 residues in random coil $(42.72 \%)$ followed by 165 residues in alpha helical region $(38.72 \%)$ and 79 residues in extended strands (18.54\%) (Data shown in E-Suppl. File Fig. 4). Wall et al. reported that any modifications in the peptide secondary structure change the capacity of its antioxidant nature. Yuan et al. demonstrated that the antioxidant efficiency was decreased when the modifications happened in the yogurt peptide $\alpha$-helical structure; also, the modification leads to changes in structural as well as functional pattern of $\beta$-sheet and random coil configuration, which represents the importance of secondary structure. Moreover, the secondary structure of corn protein hydrolysates was determined under circular dichroism that shows the lower $\alpha$-helix is the major cause of strong antioxidant activity [38]. In our case, the secondary structure of $A p A H c$ has lower $\alpha$-helix $(38.72 \%)$ than random coil $(42.72 \%)$ which signifies earlier concept that the protein has a potent antioxidant property.

We have also predicted the three-dimensional structure of $A p A H c$ using I-TASSER program and the structure was evaluated based on the C-score value and Ramachandran plot analysis. Based on those, the best model selected from the five obtained models which is having $87.7 \%$ residues in the favourable region, $9 \%$ in the allowed region and only $3.3 \%$ in the unfavourable region. The $\mathrm{C}$-score value of the best model was calculated as 1.28. Further, the model was subjected to PyMoL analysis and highlighted the different domain and motifs of ApAHc (Data shown in E-Suppl. File Fig. 5). Appaiah and Vasu [40] reported that the best model may be selected based on c-score value $(-3.29)$ with TM-Score $0.35 \pm 0.12$ and RMSD $11.3 \pm 4.5 \AA$. In this study, we observed the best c-value among the five model was -5 and its respective TM-score $(0.88 \pm 0.07)$ and $\operatorname{RMSD}(4.4 \pm 2.9 \AA)$ score signifies the model have higher confidence.

\section{Peptide characterisation}

Based on the highly conserved regions, a peptide sequence ${ }^{83}$ NPLSTQDDVAASL ${ }^{95}$ named NL13 was obtained from the $A p \mathrm{AHc}$ protein which predicted with antioxidant properties. The HPLC analysis showed the purity of the peptide as $96.2 \%$ followed by the MALDI-TOF Mass spectroscopy confirmed the sequence. The molecular weight, isoelectric point and net charge of the peptide was $1.33 \mathrm{k} \mathrm{Da}, 0.54$ and -2 , respectively. Moreover, the peptide signifies the hydrophobicity $46.15 \%$, acidic nature $15.33 \%$ and neutral nature $38.46 \%$. The helical wheel structure projects the amphipathic nature of NL13 which is possessed with both hydrophobic and hydrophilic nature (Data shown in E-Suppl. File Fig. 6). Branched-chain amino acids including leucine, valine and isoleucine have found to be used as an antioxidant or antiinflammatory products in the pharmaceutical industry [39]. Potential amino acids have shown strong antioxidant activity in Leucine than Isoleucine in Corn protein hydrolysates [38]. In accordance with the statement, our peptide NL13 also contained leucine (position 3 and 13) and valine (position 9) which predicted its potential antioxidant properties. Further Wattanasiritham et al. [20] reported that along with leucine and valine, alanine exhibit a higher antioxidant activity. It is noted that in our peptide sequence position 10 and 11 was occupied with alanine, position 3 and 13 was occupied with leucine and position 9 by valine. Proline has been considered as a non-enzymatic antioxidant residue because it is an efficient scavenger of $\mathrm{OH}^{\cdot}$ and ${ }^{1} \mathrm{O}_{2}$; that also prevents 
the damage due to lipid peroxidation [40]. It is interesting to note that NL13 contained proline at position 2, hence it is expected to function as reported. Moreover, antioxidant properties are also based on the hydrophobicity and the presence of aromatic amino acids. Also, it is reported [22] that the peptides with more than $1 \mathrm{k}$ Da have found to show the highest antioxidant activity in African Bean seed protein hydrolysate fractions, which is relevant to our peptide, NL13 that is having a molecular weight of $1.33 \mathrm{k} \mathrm{Da}$.

\section{Antioxidant property of NL13 peptide}

\section{DPPH assay}

Ethanolic DPPH absorbance level for DPPH radical scavenging was found significantly $(\mathrm{P}<0.05)$ more $(67.6 \pm 1.86)$ at higher concentration of the peptide $(250 \mu \mathrm{M})$ and less $(23.9 \pm 0.91)$ at lower concentration of peptide $(7.8 \mu \mathrm{M})$, whereas Trolox showed significantly $(\mathrm{P}<0.05)$ higher activity $(96.5 \pm 0.67)$ at higher concentration $(250 \mu \mathrm{M})$ and lower $(75.35 \pm 1.86)$ at lower concentration of the peptide $(7.8 \mu \mathrm{M})$ (Fig. 2a). Mostly free radicals showed higher activities and remain for a shorter period of time but DPPH remains stable at room temperature [23]. Similarly, Xie et al. [41] reported that the highest antioxidant activity was found $80 \%$ at $16 \mathrm{mg} /$ $\mathrm{ml}$ which was similar to GSH at $0.4 \mathrm{mg} / \mathrm{ml}$. Moreover, Sannasimuthu et al. [22] also showed that the LL12 peptide from A. platensis has high radical scavenging activity at higher concentration of the peptide, likewise in the lower concentration of the peptide. However, considering the earlier reports, NL13 produced a better radical scavenging activity.

\section{ABTS assay}

The ABTS (2,2'-azino-bis-3-ethylbenzothiazoline-6-sulfonic acid) radical assay utilises the coloured cationic radicals (ABTS) to check the capacity of antioxidants to quench the radicals [42]. It works on the principle that metametmyoglobin-hydrogen peroxideutilized generated hydroxyl radicals, that react with ABTS to form cation radicals. The assay exhibited significantly $(\mathrm{P}<0.05)$ higher antioxidant activity $(80.47 \pm 1.47)$ at the concentration of $250 \mu \mathrm{M} \mathrm{NL} 13$ and lower antioxidant activity $(41.07 \pm 0.72)$ at the concentration of $7.8 \mu \mathrm{M}$ NL13, however both the obtained high and low activity readings was not greater than the Trolox level (Fig. 2b). Recently reported, GM15 peptide derived from cyanobacteria exhibited $70.18 \pm 1.1$ at $6.25 \mu \mathrm{M}$ [17]. However, NL13 peptide showed comparatively lower activity $(41.07 \pm 0.72)$ at similar concentration $7.8 \mu \mathrm{M}$. Peptides with dominating amino acids including Glu (19.51\%), Lys (7.6\%), Pro $(7.3 \%)$ and least amount of Ser (1.5\%), Trp (1.3\%) and
Cys (0.5\%) exhibited to have high scavenging free radicals [43]. The negatively charged amino acids such as glutamic acid and aspartic acid also provide free radical to quench activity by its excess electrons [44]. NL13 is dominated by antioxidant amino acids with Asp (15.4\%), Ala (15.38\%), Leu (15.4\%), Ser (15.4\%) with other least amount amino acids Pro (7.7\%), Val (7\%) together with it have contributed towards the antioxidant property. It is reported that the presence of Pro-Leu and Ser-Leu motifs particularly at N and C terminal has seemed to show more scavenging activities, which is in accordance with our results.

\section{Hydroxyl radical scavenging (HRS) assay}

The hydroxyl radical scavenging assay was performed to analyse the effect of NL13 peptide on the hydroxyl radical trapping potential. In a biological system, hydroxyl radical acts as a highly reactive free radical that can damage molecules including DNA, lipids and proteins which are found in the living system [45]. In this study, NL13 showed $87.4 \pm 0.88$ at the concentration of $250 \mu \mathrm{M}$ and $57.63 \pm 1.55$ at the concentration of $7.8 \mu \mathrm{M}(\mathrm{P}<0.05)$, whereas the Trolox showed $91.8 \pm 2.28$ at the concentration of $250 \mu \mathrm{M}$ and $75.066 \pm 1.8$ at the concentration of $7.8 \mu \mathrm{M}$ (Fig. 2C). Similarly, Xie et al. [41] reported that soy proteins hydrolysates have found to show the highest hydroxyl scavenging activity which is in accordance with our findings. Sun et al. [46] also reported that PHH-IV peptide derived from Procine haemoglobin hydrolysate less than $3 \mathrm{kDa}$ exhibited the highest antioxidant capacity compared to the other peptides derived with higher molecular weight. Proline is a very effective scavenger of hydroxyl ions and peptide NL13 contains Proline (7.7\%), it is predicted that the highest activity may be due to the presence of Proline. It is known that excess hydroxyl radical causes damage in biological system, it has been maintained at an optimum level. Considering the statement, it is suggested that NL13 could act as radical scavenger for hydroxyl radicals, so as to protect from oxidative damage.

\section{Superoxide anionic radical scavenging assay}

Superoxide anion radical is highly toxic that produced in different cellular reactions and acts as a weak oxidant. Also, a basic radical lead to the formation of singlet oxygen and hydrogen peroxide. Superanion oxide which is derived from the dissolved $\mathrm{O}_{2}$ in Phenazine methosulphate/Nicotinamide adenine dinucleotide coupling reaction leads to reduction of NBT [47]. The reaction with NL13 has shown a decrease in the absorbance and indicated that the antioxidant capacity may be consumed or 


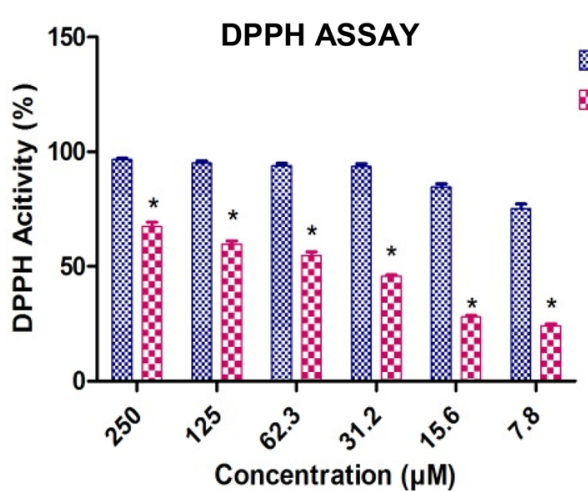

(A)

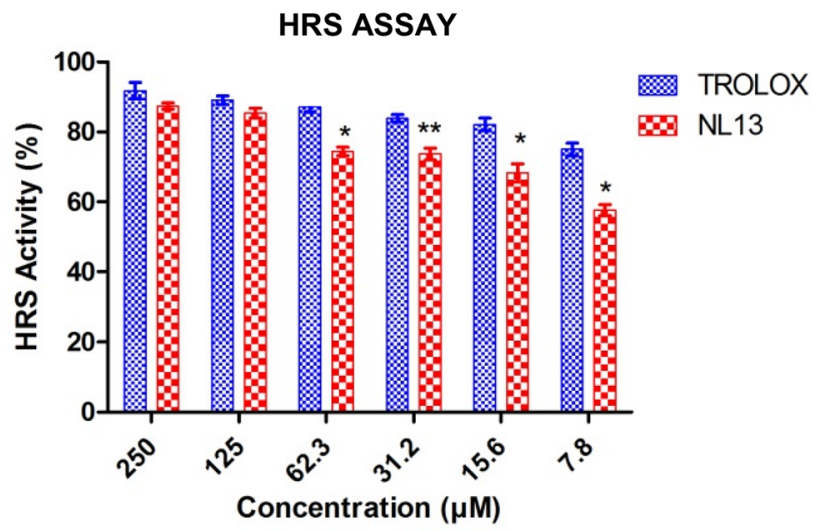

(C)

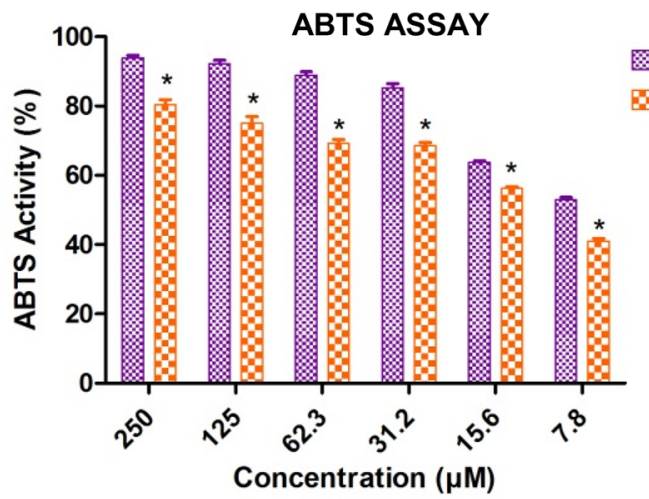

(B)

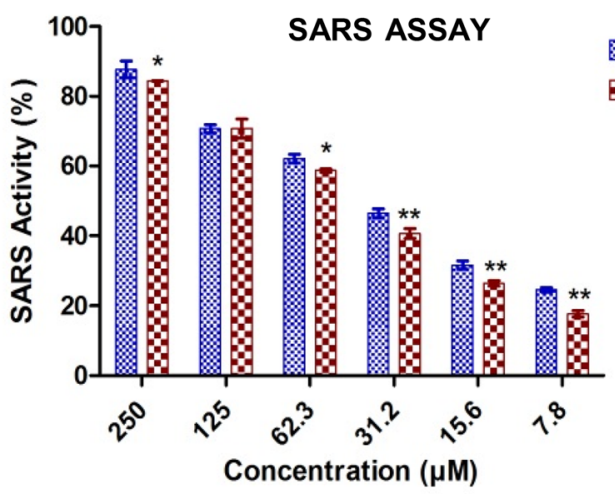

(D)

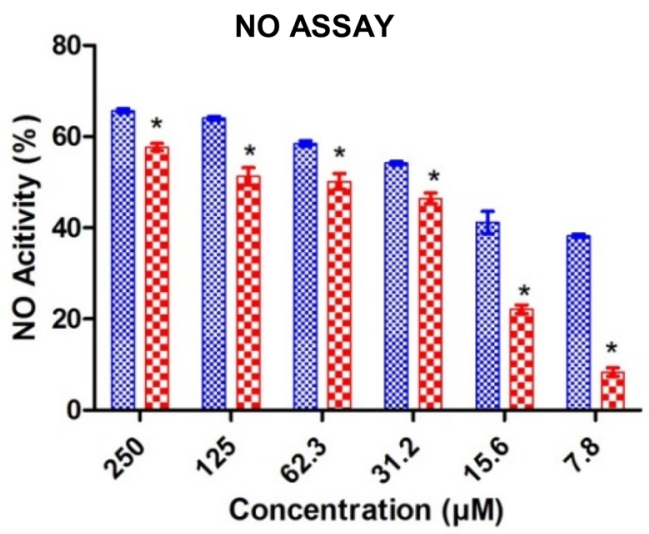

Trolox

NL13

(E)

Fig. 2 Radical scavenging ability of NL13 peptide was compared with that of standard antioxidant Trolox. a 2,2-diphenyl-1-picryly hydrazyl assay on DPPH radical, b 2,2-azino-bis-3-ethylbenzothiazoline-6-sulfonic acid assay on ABTS radical, $\mathbf{c}$ hydroxly radical scavenging assay on hydroxyl ions, $\mathbf{d}$ superoxide anion radical scavenging assay on superoxide anion radical and e nitric oxide assay on Nitric oxide radical at different concentration. The single asterisk $\left(^{*}\right)$ and double asterisk $(* *)$ denotes the significant different between control (Trolox) and treatments (NL13 conc. 250 to $7.8 \mu \mathrm{M}$ ) at $\mathrm{P}<0.05$ and $\mathrm{P}<0.01$ level by Borferonni post Hoc test. All values were given in mean of three replicates \pm standard deviation 
inactivated by superoxide anion radicals developed during the reaction. The reaction mixture with peptide was found to be $84.45 \pm 0.98$ compared to Trolox $87.74 \pm 2.3$ at the peptide concentration of $250 \mu \mathrm{M}$ (Fig. 2d). Whereas, at lowest concentration $(7.8 \mu \mathrm{M})$ the activity in the treatment was $17.69 \pm 0.933$ and in Trolox it was $24.57 \pm 0.57$ which is significantly $(\mathrm{P}<0.01)$ better than the treatment. According to Suetsuna et al. the presence of Glycine and Leucine residues has contributed to higher superoxide anionic radical scavenging rate in the peptide derived from Caesin [48]. In our sequence, it was noticed that the presence of leucine (15.4\%) in NL13 may have contributed towards the better scavenging activity.

\section{Nitric oxide assay}

Nitric oxide is an intense pleiotropic among different physiological activities. It is a diffusible free radical, which plays numerous roles as an effector particles in various organic frameworks. Antioxidant activity was estimated $65.7 \pm 0.48$ $(250 \mu \mathrm{M})$ in Trolox and in NL13 it was $57.69 \pm 0.81$, which is comparatively significant $(\mathrm{P}<0.05)$. However, at lower concentration $(7.8 \mu \mathrm{M})$, NL13 did not show any potential nitric oxide scavenging activity $(8.353 \pm 0.33)$ (Fig. 2e). Tsikas reported that the generation of nitric oxide due to the interaction of oxygen with sodium nitroprusside that is producing nitric ions by Griess reaction, further the diazotization of nitrate with sulphanilamide and coupling with NEED involved in the reaction mixture, thus reducing the damages [49].

\section{Cytotoxicity assay on human whole blood and intracellular ROS on leucocytes}

Haemolytic assay was performed on human whole blood cells. Haemolysis of whole blood cells was done at higher concentration of peptide and compared with Triton X-100 as positive control and PBS as a negative control. NL13 showed significant $(\mathrm{P}<0.01)$ difference with Triton $\mathrm{X}-100$ and no lysis was observed even at higher concentration (Fig. 3). Cytotoxicity of the blood is an important parameter for peptide therapeutic applications [50], hence the assay was performed on Human whole blood that showed no haemolysis of blood even at higher concentration $(250 \mu \mathrm{M})$.

Intracellular ROS was performed using DCF assay dye and $\mathrm{H}_{2} \mathrm{O}_{2}$ was used as a radical generator which provides oxidative stress to the leucocytes. In this assay, we employed fluorometric study to analyse the percentage of intracellular ROS production at different concentration of peptide, thus determining the reduction in ROS production. Scavenging

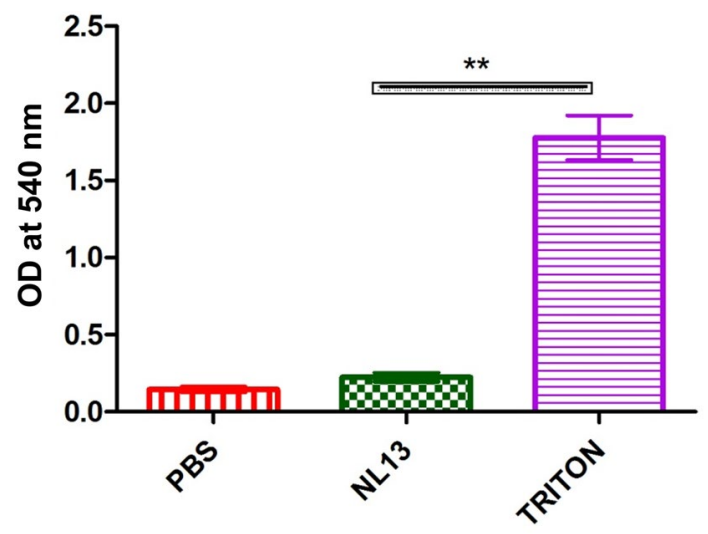

Fig. 3 The haemolytic assay performed on human whole blood with Triton-X as positive control and PBS as negative control. Values are shown in mean \pm SD of three replicates. The double asterisk $(* *)$ represents the significance $(\mathrm{P}<0.01)$ of peptide (conc. $250 \mu \mathrm{M})$ compared with Triton-X measured using Tukey's Multiple Comparison Test using Graph Pad Prism 5.0

of ROS production was found at different concentration of NL13 where the highest $(60.52 \%)$ was observed at $250 \mu \mathrm{M}$ which significantly $(\mathrm{P}<0.05)$ decreases $(52.65 \%)$ at $31.2 \mu \mathrm{M}$. Cells stained with DCFH-DA colour were treated with different concentration of NL13 $(62.3,125$ and $250 \mu \mathrm{M})$ and observed beneath a fluorescence magnifying instrument and the result was compared with the control group (Fig. 4). ROS production was more (20\%) in THP-1 and L-6 at lowest concentration $(10 \mu \mathrm{M})[26]$ which is comparatively higher than NL13, however in NL13 the scavenging activity was high at higher concentration $(250 \mu \mathrm{M})$. Sannasimuthu et al. [20] showed scavenging activity even at lower concentration $(12.5 \mu \mathrm{M})$ of spirulina peptide, but in our case the peptide function in a dose dependent manner on leucocytes.

\section{Cell viability and wound healing activity on VERO cells}

Cell viability assay was performed on VERO cells using MTT assay and found that NL13 was safer (Fig. 5). In this study, we noticed that NL13 did not show any cytotoxicity even at the high concentration $(250 \mu \mathrm{M})$. It indicates the safeness of peptide for therapeutic usages. Therefore, an optimum concentration of peptide $(31.2 \mu \mathrm{M})$ was selected for the further study. Inflammation, cell proliferation and remodelling are the stages of wound healing. Formation of epithelial cells at the edges of the wounds include the keratinocytes formation and construction of the basement membrane. 


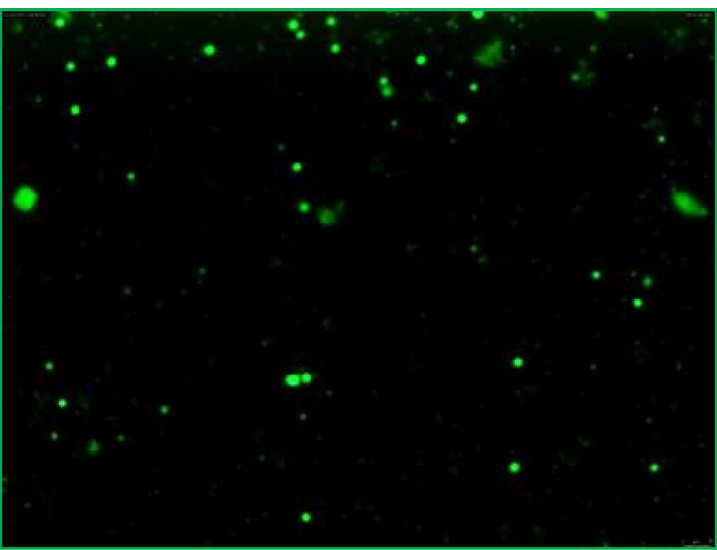

(A)

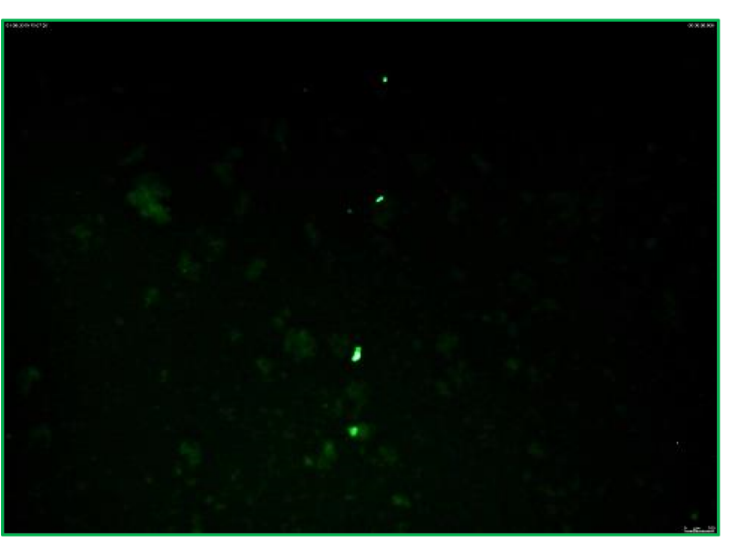

(C)

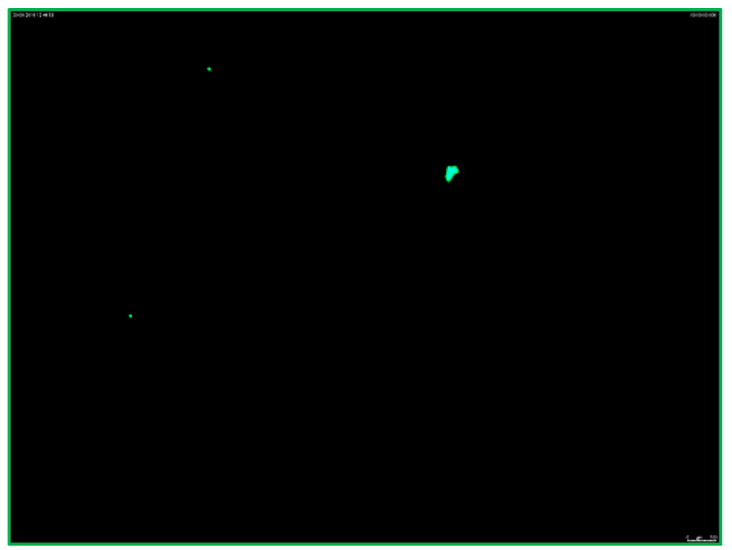

(B)

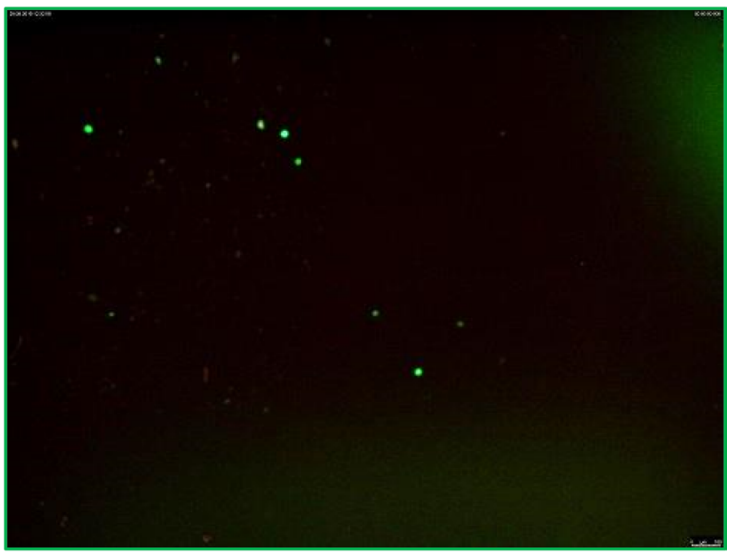

(D)

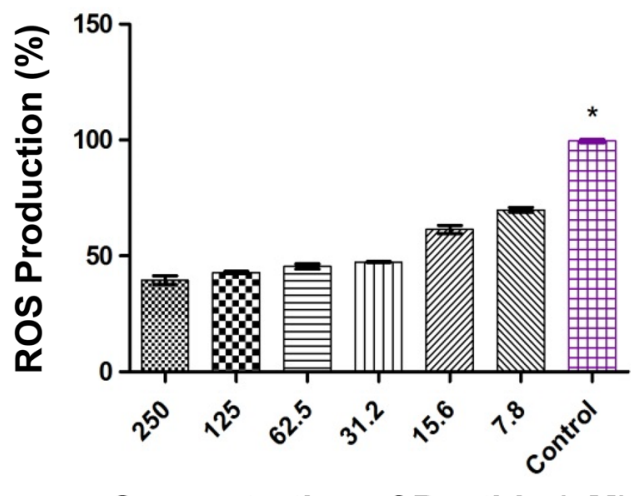

Concentration of Peptide $(\mu \mathrm{M})$

(E)

Fig. 4 Reduction in intracellular ROS production in human leucocytes by NL13 peptide after stimulation with DCF dye as Hydrogen peroxide as free radical generator. Microscopic images (magnification $=10 \times$ and Scale bar $=100 \mu \mathrm{m}$ ) taken at different concentrations: a Control (without treatment), b NL13 at $250 \mu \mathrm{M}$, c NL13 at $125 \mu \mathrm{M}$, d NL13 at $62.3 \mu \mathrm{M}$, e fluorometric analysis of different concentration of peptides against ROS production. Single asterisk (*) represents $\mathrm{P}<0.05$ compared to the control by Tukey's Multiple Comparison test in Graph Pad 5.0. The values were provided in mean of three replicates \pm standard deviation 


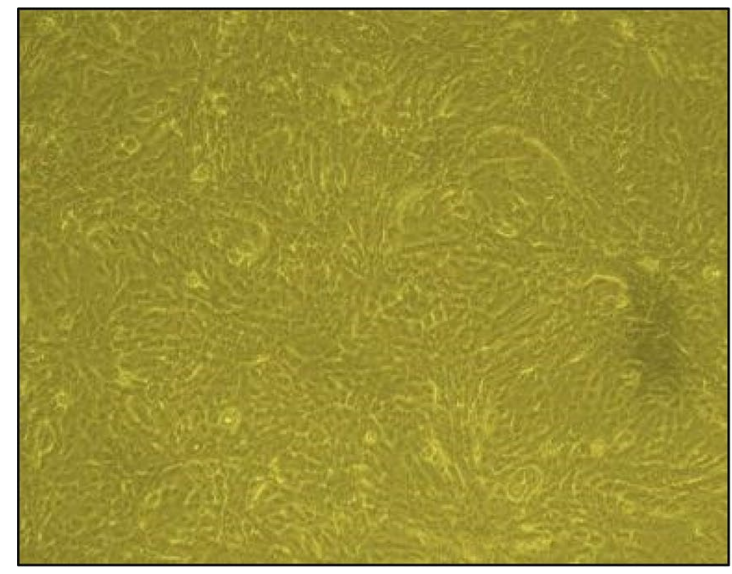

(A)

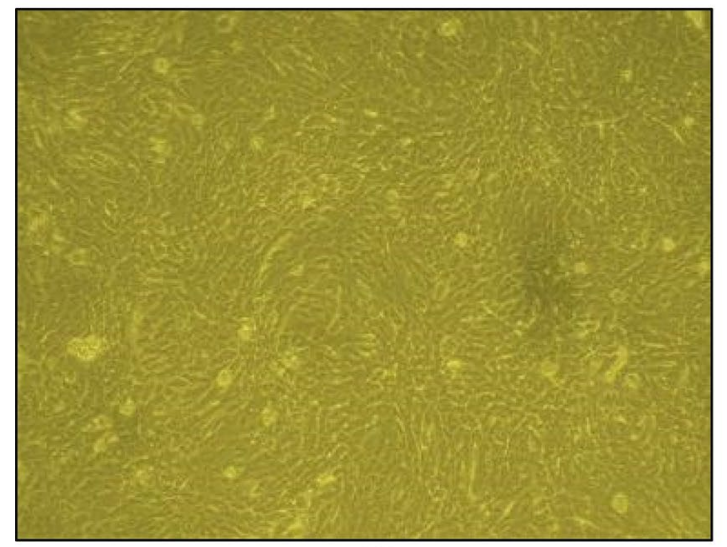

(C)

Fig. 5 NL13 induced cell viability assay. VERO cells $\left(1 \times 10^{6}\right.$ cells/ well) were seeded onto a 96 well-plate and incubated for $24 \mathrm{~h}$ with NL13 peptide at different concentration (250-7.8 $\mu \mathrm{M})$. Microscopic images $(10 \times)$ were obtained for Control $(\mathbf{a})$, lowest peptide concentration treated $(7.8 \mu \mathrm{M})(\mathbf{b})$ and highest concentration peptide treated

In our study, cell migration assay on VERO cells was performed at two different interval of time ( 24 and $48 \mathrm{~h}$ ) and compared the results where the cells were treated with NL13 peptide and control (without NL13 peptide). The cell migration was noticed at $24 \mathrm{~h}(31.02 \%)$ in treatment and in control it was only $17.24 \%$, whereas at $48 \mathrm{~h}$ the scenario was $82.76 \%$ in treatment and in control it was $62.07 \%$. The cell migration rate was significantly $(\mathrm{P}<0.05)$ higher in treated group than the control group (Fig. 6). Lee et al. [51] reported that HaCaT assay on AES16-2 M peptide showing effective cell migration at $16 \mathrm{~h}$, in our case it was $24 \mathrm{~h}$. However, the cell migration for NL13 was effective at $24 \mathrm{~h}$ of treatment. In comparison with the treated and untreated cells, the peptide

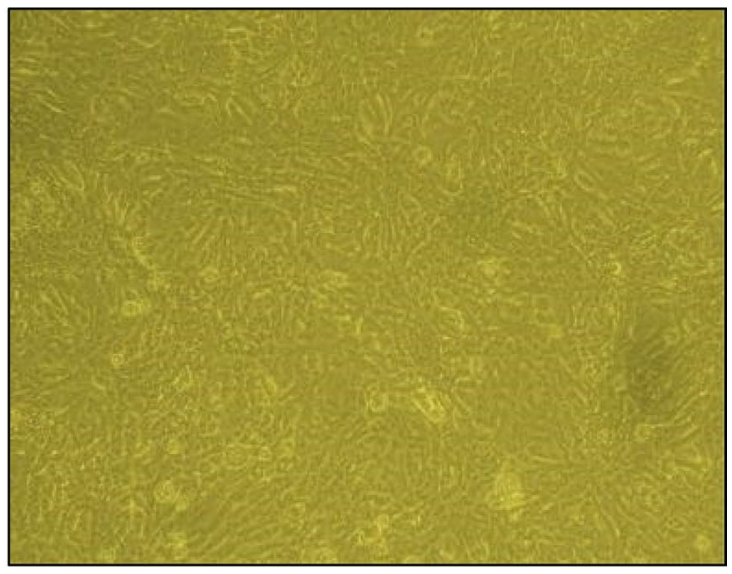

(B)

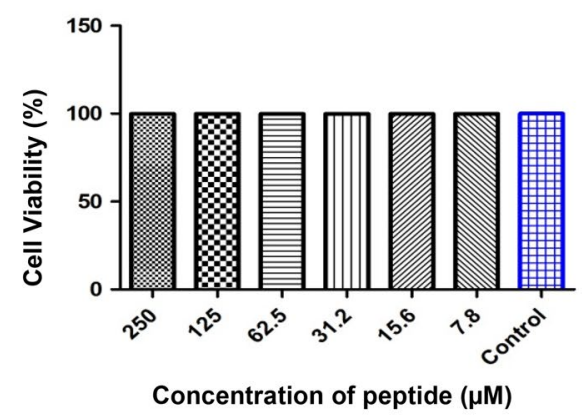

(D)

$(250 \mu \mathrm{M})(\mathbf{c})$. d MTT assay was performed on VERO cells with NL13 peptide at different concentration $(250-7.8 \mu \mathrm{M})$ where PBS served as control. Bar diagram was showed the cell viability against different concentration of peptide measured in Microplate Reader $(\mathrm{n}=3)$

treated cells are showing significantly faster relief than the untreated cells, thus the peptide NL13 effectively function on wound healing process. Effective wound healing activity was observed in peptides C2 and E1 on VERO cells [52]. Amino acids such as argenine and glutamine influences the wound healing activity by functioning through the immune system [23]. Proline is an amino acid that is present in collagen which is an essential connective tissue protein accelerating healing effects [53]. It has been reported that glycine, proline, hydroxyproline and alanine are the largest collagen molecules followed by serine, threonine, aspartic acid and Glutamic acid [54, 55]. NL13 has proline (at position 2), alanine (at position 10 and 11), serine (at position 4 and 12) and threonine (at position 5). 
Fig. 6 NL13 peptide influence VERO cell migration. VERO cells were treated with NL13 at an optimum concentration of $31.2 \mu \mathrm{M}$ and control (Peptide free medium) was maintained for 0,24 , and $48 \mathrm{~h}$. The images were photographed at magnification of 10X. The area of wound was measured by Image $J$ and the Wound healing percentage was calculated as the ratio of the remaining area to that at $0 \mathrm{~h}(n=3)$ which was given in the line graph. Single asterisk $\left(^{*}\right)$ represents $\mathrm{P}<0.05$ compared to their respective controls by Bonferroni post hoc test in Graph Pad 5.0
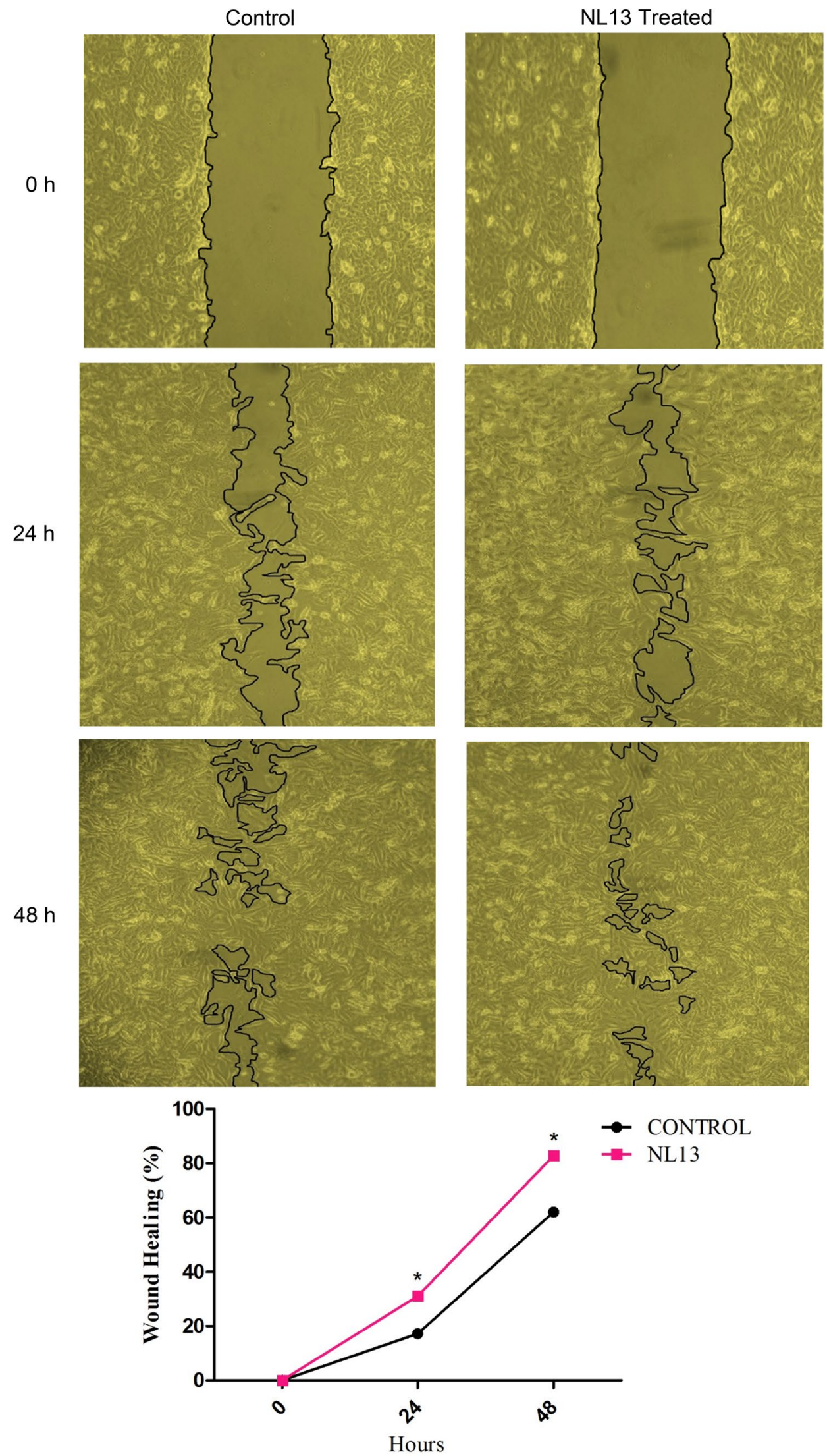

CONTROL

NL13 
The presence of these amino acids may have influenced the wound healing activity on VERO cells. Also, since NL13 peptide was found to reduce the ROS production on human leukocytes which could also have influenced to increase the cell migration rate on VERO cells.

Acknowledgements The authors would like to extend their sincere appreciation to the Deanship of Scientific Research at the King Saud University, Riyadh, Saudi Arabia for funding this Research Group Project (No. RGP-289)

\section{Compliance with ethical standards}

Conflict of interest The authors declare that they have no conflict of interest.

Research involving human and animal participants For human blood collection, informed consent was obtained from all the participated adults in written form as per the Institute ethical approval (Ethical Clearance No. CDRI/IEC/2014/A1). No Animal were used for studies that are base of this research.

\section{References}

1. Zhang Z, Pendse ND, Phillips KN et al (2008) Gene expression patterns of sulfur starvation in Synechocystis sp. PCC 6803. BMC Genom. https://doi.org/10.1186/1471-2164-9-344

2. De La Haba G, Cantoni GL (1959) The enzymatic synthesis of S-adenosyl-L-homocysteine from adenosine and homocysteine. J Biol Chem 234:603-608

3. Palmex JL, Abeles RH (1979) The mechanism of action of S-adenosylhomocysteinase. J Biol Chem 254:1217-1226

4. Yang X, Hu Y, Yin DH et al (2003) Catalytic strategy of S-adenosyl-L-homocysteine hydrolase: transition-state stabilization and the avoidance of abortive reactions. Biochemistry. https:// doi.org/10.1021/bi0262350

5. Singer AJ, Clark RAF (1999) Cutaneous wound healing. N Engl J Med 341:738-746. https://doi.org/10.1056/NEJM19990902341 1006

6. Süntar I, Akkol EK, Nahar L, Sarker SD (2012) Wound healing and antioxidant properties: do they coexist in plants? Free Radic Antioxid 2:1-7. https://doi.org/10.5530/ax.2012.2.2.1

7. Houghton PJ, Hylands PJ, Mensah AY et al (2005) In vitro tests and ethnopharmacological investigations: wound healing as an example. J Ethnopharmacol 100:100-107. https://doi. org/10.1016/j.jep.2005.07.001

8. Annan K, Houghton PJ (2008) Antibacterial, antioxidant and fibroblast growth stimulation of aqueous extracts of Ficus asperifolia Miq. and Gossypium arboreum L., wound-healing plants of Ghana. J Ethnopharmacol 119:141-144. https://doi.org/10.1016/j. jep.2008.06.017

9. Finamore A, Palmery M, Bensehaila S, Peluso I (2017) Antioxidant, immunomodulating, and microbial-modulating activities of the sustainable and ecofriendly spirulina. Oxid Med Cell Longev. https://doi.org/10.1155/2017/3247528

10. Abdel-Daim M, El-Bialy BE, Rahman HGA et al (2016) Antagonistic effects of Spirulina platensis against sub-acute deltamethrin toxicity in mice: biochemical and histopathological studies. Biomed Pharmacother 77:79-85. https://doi.org/10.1016/j.bioph a. 2015.12 .003
11. Miranda MS, Cintra RG, Barros SBM, Mancini-Filho J (1998) Antioxidant activity of the microalga Spirulina maxima. Brazilian J Med Biol Res 31:1075-1079. https://doi.org/10.1590/S0100 -879 X1998000800007

12. Zaid AAA, Hammad DM, Sharaf EM (2015) Antioxidant and anticancer activity of Spirulina platensis water extracts. Int J Pharmacol 11:846-851. https://doi.org/10.3923/ijp.2015.846.851

13. Bermejo-Bescós P, Piñero-Estrada E, Villar del Fresno ÁM (2008) Neuroprotection by Spirulina platensis protean extract and phycocyanin against iron-induced toxicity in SH-SY5Y neuroblastoma cells. Toxicol Vitro 22:1496-1502. https://doi.org/10.1016/j. tiv.2008.05.004

14. Vijayakumar S, Menakha M (2015) Pharmaceutical applications of cyanobacteria-a review. J Acute Med 5:15-23

15. Singh R, Parihar P, Singh M et al (2017) Uncovering potential applications of cyanobacteria and algal metabolites in biology, agriculture and medicine: current status and future prospects. Front. Microbiol 8:515

16. Tao J, Zhao YQ, Chi CF, Wang B (2018) Bioactive peptides from cartilage protein hydrolysate of spotless smoothhound and their antioxidant activity in vitro. Mar Drugs. https://doi.org/10.3390/ md16040100

17. Sannasimuthu A, Kumaresan V, Anilkumar S et al (2019) Design and characterization of a novel Arthrospira platensis glutathione oxido-reductase-derived antioxidant peptide GM15 and its potent anti-cancer activity via caspase- 9 mediated apoptosis in oral cancer cells. Free Radic Biol Med 135:198-209. https://doi. org/10.1016/j.freeradbiomed.2019.03.006

18. Cojocaru E, Filip N, Ungureanu C et al (2014) Effects of valine and leucine on some antioxidant enzymes in hypercholesterolemic rats. Health 06:2313-2321. https://doi.org/10.4236/healt h. 2014.617266

19. Sohaib M, Anjum FM, Sahar A et al (2017) Antioxidant proteins and peptides to enhance the oxidative stability of meat and meat products: a comprehensive review. Int J Food Prop 20:2581-2593. https://doi.org/10.1080/10942912.2016.1246456

20. Kumaresan V, Nizam F, Ravichandran G et al (2017) Transcriptome changes of blue-green algae, Arthrospira sp. in response to sulfate stress. Algal Res 23:96-103. https://doi.org/10.1016/j.algal .2017 .01 .012

21. Sannasimuthu A, Arockiaraj J (2019) Intracellular free radical scavenging activity and protective role of mammalian cells by antioxidant peptide from thioredoxin disulfide reductase of Arthrospira platensis. J Funct Foods 61:103513. https://doi. org/10.1016/j.jff.2019.103513

22. Sannasimuthu A, Kumaresan V, Pasupuleti M et al (2018) Radical scavenging property of a novel peptide derived from C-terminal SOD domain of superoxide dismutase enzyme in Arthrospira platensis. Algal Res 35:519-529. https://doi.org/10.1016/j.algal .2018.09.028

23. MacKay D, Miller AL (2003) Nutritional support for wound healing. Altern Med Rev 8:359-377

24. Marcocci L, Maguire JJ, Droy-Lefaix MT, Packer L (1994) The nitric oxide-scavenging properties of Ginkgo biloba extract EGb 761. Biochem Biophys Res Commun 201:748-755. https://doi. org/10.1006/bbrc. 1994.1764

25. Ravichandran G, Kumaresan V, Arasu MV et al (2016) Pellino-1 derived cationic antimicrobial prawn peptide: bactericidal activity, toxicity and mode of action. Mol Immunol 78:171-182. https:// doi.org/10.1016/j.molimm.2016.09.015

26. Bernini R, Barontini M, Cis V et al (2018) Synthesis and evaluation of the antioxidant activity of lipophilic phenethyl trifluoroacetate esters by in vitro ABTS, DPPH and in cell-culture DCF assays. Molecules. https://doi.org/10.3390/molecules23010208 
27. Mosmann T (1983) Rapid colorimetric assay for cellular growth and survival: application to proliferation and cytotoxicity assays. J Immunol Methods. https://doi.org/10.1016/0022-1759(83)90303 $-4$

28. Felice F, Zambito Y, Belardinelli E et al (2015) Effect of different chitosan derivatives on in vitro scratch wound assay: a comparative study. Int J Biol Macromol 76:236-241. https://doi. org/10.1016/j.ijbiomac.2015.02.041

29. Hermes M, Osswald H, Riehle R et al (2008) S-adenosylhomocysteine hydrolase overexpression in HEK-293 cells: effect on intracellular adenosine levels, cell viability, and DNA methylation. Cell Physiol Biochem 22:223-236. https://doi.org/10.1159/00014 9800

30. Singhal A, Arora G, Sajid A et al (2013) Regulation of homocysteine metabolism by Mycobacterium tuberculosis S-adenosylhomocysteine hydrolase. Sci Rep. https://doi.org/10.1038/srep02264

31. Kerins DM, Koury MJ, Capdevila A et al (2001) Plasma S-adenosylhomocysteine is a more sensitive indicator of cardiovascular disease than plasma homocysteine. Am J Clin Nutr 74:723-729. https://doi.org/10.1093/ajen/74.6.723

32. Xiao Y, Xia J, Cheng J et al (2019) Inhibition of S-adenosylhomocysteine hydrolase induces endothelial dysfunction via epigenetic regulation of p66shc-mediated oxidative stress pathway. Circulation 139:2260-2277. https://doi.org/10.1161/CIRCULATIO NAHA.118.036336

33. Balado M, Lages MA, Fuentes-Monteverde JC et al (2018) The siderophore piscibactin is a relevant virulence factor for vibrio anguillarum favored at low temperatures. Front Microbiol 9:1766. https://doi.org/10.3389/fmicb.2018.01766

34. Gault PM, Marler HJ, Li Z In: Handbook on Cyanobacteria. Advances in Marine Symbiotic Cyanobacteria

35. Yasin D, Zafaryab M, Ansari S et al (2019) Evaluation of antioxidant and anti-proliferative efficacy of Nostoc muscorum NCCU-442. Biocatal Agric Biotechnol 17:284-293. https://doi. org/10.1016/j.bcab.2018.12.001

36. Hossain MF, Ratnayake RR, Meerajini K, Wasantha Kumara KL (2016) Antioxidant properties in some selected cyanobacteria isolated from fresh water bodies of Sri Lanka. Food Sci Nutr 4:753-758. https://doi.org/10.1002/fsn3.340

37. Li X, Huang L, Hong $Y$ et al (2015) Co-silencing of tomato $\mathrm{S}$-adenosylhomocysteine hydrolase genes confers increased immunity against Pseudomonas syringae pv. Tomato DC3000 and enhanced tolerance to drought stress. Front Plant Sci. https:// doi.org/10.3389/fpls.2015.00717

38. Jiang Y, Zhang M, Lin S, Cheng S (2018) Contribution of specific amino acid and secondary structure to the antioxidant property of corn gluten proteins. Food Res Int 105:836-844. https://doi. org/10.1016/j.foodres.2017.12.022

39. Jin HJ, Lee JH, Kim DH et al (2015) Antioxidative and nitric oxide scavenging activity of branched-chain amino acids. Food Sci Biotechnol 24:1555-1558. https://doi.org/10.1007/s1006 8-015-0200-2

40. Das K, Roychoudhury A (2014) Reactive oxygen species (ROS) and response of antioxidants as ROS-scavengers during environmental stress in plants. Front Environ Sci. https://doi.org/10.3389/ fenvs.2014.00053
41. Xie Z, Huang J, Xu X, Jin Z (2008) Antioxidant activity of peptides isolated from alfalfa leaf protein hydrolysate. Food Chem 111:370-376. https://doi.org/10.1016/j.foodchem.2008.03.078

42. Khatua S, Ghosh S, Acharya K (2017) Simplified methods for microtiter based analysis of in vitro antioxidant activity. Asian J Pharm 11:S327-S335. https://doi.org/10.22377/ajp.v11i02.1272

43. He R, Ju X, Yuan J et al (2012) Antioxidant activities of rapeseed peptides produced by solid state fermentation. Food Res Int 49:432-438. https://doi.org/10.1016/j.foodres.2012.08.023

44. Bin Zou T, He TP, Bin Li H et al (2016) The structure-activity relationship of the antioxidant peptides from natural proteins. Molecules 21:1-14. https://doi.org/10.3390/molecules21010072

45. Loganayaki N, Siddhuraju P, Manian S (2013) Antioxidant activity and free radical scavenging capacity of phenolic extracts from Helicteres isora L. and Ceiba pentandra L. J Food Sci Technol 50:687-695. https://doi.org/10.1007/s13197-011-0389-x

46. Sun Q, Shen H, Luo Y (2011) Antioxidant activity of hydrolysates and peptide fractions derived from porcine hemoglobin. J Food Sci Technol 48:53-60. https://doi.org/10.1007/s1319 7-010-0115-0

47. Pavithra K, Vadivukkarasi S (2015) Evaluation of free radical scavenging activity of various extracts of leaves from Kedrostis foetidissima (Jacq.) Cogn. Food Sci Hum Wellness 4:42-46. https ://doi.org/10.1016/j.fshw.2015.02.001

48. Suetsuna K, Ukeda H, Ochi $\mathrm{H}$ (2000) Isolation and characterization of free radical scavenging activities peptides derived from casein. J Nutr Biochem 11:128-131

49. Tsikas D (2007) Analysis of nitrite and nitrate in biological fluids by assays based on the Griess reaction: appraisal of the Griess reaction in the L-arginine/nitric oxide area of research. J Chromatogr, B: Anal Technol Biomed Life Sci 851:51-70. https://doi. org/10.1016/j.jchromb.2006.07.054

50. Gordon YJ, Romanowski EG, McDermott AM (2005) Mini review: a review of antimicrobial peptides and their therapeutic potential as anti-infective drugs. Curr Eye Res 30:505-515

51. Lee S, Kim MS, Jung SJ et al (2018) ERK activating peptide, AES16-2 M promotes wound healing through accelerating migration of keratinocytes. Sci Rep 8:1-10. https://doi.org/10.1038/ s41598-018-32851-y

52. Ros E, Ros E (2011) Stress removal and in vitro wound healing activity of peptides C2 and E1. 140-164

53. Ponrasu T, Jamuna S, Mathew A et al (2013) Efficacy of L-proline administration on the early responses during cutaneous wound healing in rats. Amino Acids 45:179-189. https://doi.org/10.1007/ s00726-013-1486-0

54. Albaugh VL, Mukherjee K, Barbul A (2017) Proline precursors and collagen synthesis: biochemical challenges of nutrient supplementation and wound healing. J Nutr 147:2011-2017. https:// doi.org/10.3945/jn.117.256404

55. Barbul A (2008) Proline precursors to sustain Mammalian collagen synthesis. J Nutr 138:2021S-2024S. https://doi.org/10.1093/ $\mathrm{jn} / 138.10 .2021 \mathrm{~S}$

Publisher's Note Springer Nature remains neutral with regard to jurisdictional claims in published maps and institutional affiliations. 